\title{
Water Flow Model and Cost Analysis in Iron and Steel Enterprise
}

\author{
Yongjuan Tong \\ SEPA Key Laboratory on Eco-industry \\ Northeastern University \\ Shenyang, China \\ E-mail: tong_yongjuan@163.com
}

\author{
Yongjuan Tong \\ Key Laboratory for Ferrous Metallurgy and Resources \\ Utilization of Ministry of Education \\ Wuhan University of Science and Technology \\ Wuhan, China \\ E-mail: tong_yongjuan@163.com
}

\author{
Jiuju Cai \\ SEPA Key Laboratory on Eco-industry \\ Northeastern University \\ Shenyang, China \\ E-mail: rcjj@mail,neu.edu.cn \\ Lianyong Wang \\ SEPA Key Laboratory on Eco-industry \\ Northeastern University \\ Shenyang, China \\ E-mail: wly@mail,neu.edu.cn
}

\begin{abstract}
Main targets of this research project are water conservation, emission reduction and cost reduction of water resources. The water flow model of iron and steel industry is built to analyze the water-use system applied substance flow analysis. Based on the model, the water cost model is developed to analyze the change of the water cost per ton steel a decade in steel industry and the composition of water cost per ton steel in a typical iron and steel enterprise in China. The results suggest the main influencing factors and reasons for water cost, which then serve as the basis for getting a way to save water, reduce emission and cost. In addition, the results of this study and water flow and cost analysis can help guide resource managers, environmental policy makers, and environmental scientists in their efforts to save resources, reduce emissions, cost and protect environment.
\end{abstract}

Keywords-iron and steel enterprise; water cost per ton steel; water conservation; emission reduction; substance flow analysis

\section{INTRODUCTION}

Water is a vital component of iron and steel industry operations, and it is utilized for a wide range of purposes. The government is sued a plan of "Water Pollution Control Action Plan" ("Water ten" for short) on April 16, 2015. It contains the complete control for water pollutants discharge, water volume control, tough water management, strictly control of groundwater overdraft, strict industrial water saving, quick reformation of water price, increased water resources fee levy standard, etc. Industrial enterprises are forced to speed up the pace of water saving and emission reduction for reducing costs and improving the competitiveness. There is no doubt that the market competitiveness and sustainable development have become the common epoch topic of iron and steel industry. Resources saving, emission reduction and environment protection have become the strategic need of existence and development of the industry, but also the urgent request of meeting challenge and improving market competition. Water as the source of life, industrial blood, is known as the "the blood of iron and steel production", which is both a resource and an energy source, has an irreplaceable role in the process of iron and steel production [1-3].

\section{A. environmental significance of water}

Water has become an important factor for the sustainable development of economy and environment. China is seriously poor of water, which is one of the 13 main water shortage countries in the world. Average per capita water resources of China is $2200 \mathrm{~m}^{3}$, is only about one-fourth of the world's average. More than 400 cities of China which has 664 cities are short supply of water, 110 cities are serious among these. And water shortage has become a burning issue constraining China's economic and social sustained development [4]. Iron and steel industry is one of the major high water consumption and high wastewater emission industries, which accounts for about $14 \%$ of the nation total water consumption, and generates $12 \%$ of the nation total wastewater [4 7]. "The 12th Five-year Plan for economic and social development of China" stipulated that water consumption for unit of industrial added value needed to reduce $30 \%$.

\section{B. economic significance of water}

Water cost per ton steel is a "controllable cost" like energy, which occupies an important share in the controllable cost per ton steel. For enhancing the market competitiveness of the enterprise and reducing water cost per ton steel, we can optimize the utilization of water resources, research methods of water-saving and emission reduction. Related studies on steel industry are in the initial stage, and have a great potential of development.

Substance flow analysis (SFA) provides a helpful tool to the study of industrial metabolism of a certain substance (eg. aluminum and copper) in terms of a country or a 
region. The study builds up a water flow model applying SFA "following-observing" model [8 12], and analyzes the composition of water cost per ton steel and develops the water cost model. Furthermore, the study finds the main influencing factors and reas ons for water cost and the methods for water-saving and emission reduction, through analyzing the change of the water cost per ton steel a decade in steel industry and the composition of water cost per ton steel in a typical iron and steel enterprise in China.

\section{WATER FLOW MODEL IN IRON AND STEEL ENTERPRISE}

The water supply and drainage system in iron and steel enterprise is complex with many kinds of water. Fig. 1 shows the water flow model in iron and steel enterprise, it also can show a production unit or a process in an iron and steel enterprise. Four water flows enter into steel enterprise, i.e. fresh water, circulation water, series water and reused water; Four water flows flow out from steel enterprise, i.e. circulation water, series water, wastewater emission and water losses.

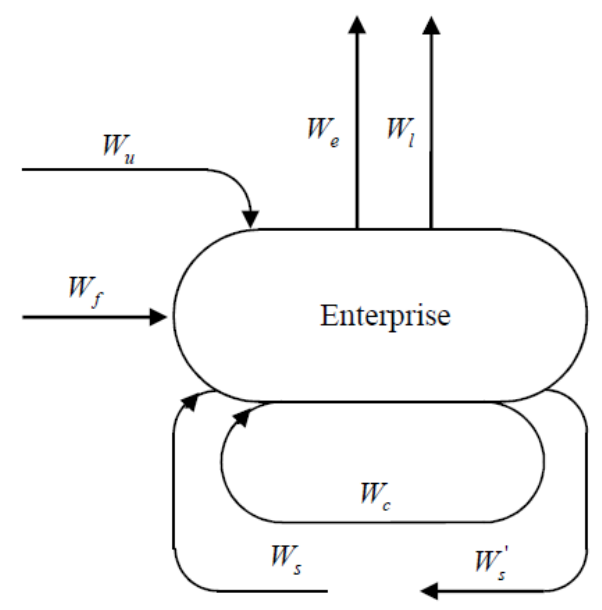

Figure 1. The water flow model in iron and steel enterprise

Based on water balance, water flow model in iron and steel enterprise is built up. The equation is

$$
W_{f}+W_{c}+W_{s}+W_{u}=W_{c}+W_{s}^{\prime}+W_{e}+W_{l}
$$

Water consumption per ton steel is

$$
W_{p}=W_{f}+W_{c}+W_{s}+W_{u}
$$

Where, $W_{p}$ represents the water consumption per ton steel, is defined as the amount of water used when a ton of steel is produced, which can assess water-use technology and measure water-saving effectiveness of a steel enterprise, $\mathrm{m}^{3} / \mathrm{t} ; W_{f}$ represents fresh water consumption per ton steel, is defined as the amount of industrial fresh water used for per ton steel, which can evaluate watersaving effectiveness of a steel enterprise, $\mathrm{m}^{3} / \mathrm{t} ; W_{c}$ represents circulation water consumption per ton steel, is defined as the amount of water recycled for per ton steel, which can reflect water-recycle technology of an enterprise, $\mathrm{m}^{3} / \mathrm{t} ; W_{s}$ represents the series water consumption per ton steel, is defined as the amount of series water used for per ton steel, $\mathrm{m}^{3} / \mathrm{t} ; W_{u}$ represents the reused water consumption per ton steel, is defined as the amount of reused water used for per ton steel, $\mathrm{m}^{3} / \mathrm{t} ; W_{e}$ represents the wastewater emission per ton steel, is defined as the amount of wastewater emission for per ton steel, which is an essential index to evaluate water-saving effectiveness and the environmental impacts of a steel enterprise, $\mathrm{m}^{3} / \mathrm{t} ; W_{l}$ represents the water losses per ton steel, is defined as the amount of water lost when a ton of steel is produced, $\mathrm{m}^{3} / \mathrm{t}$.

No matter how complicated the water species is, it can be simply divided into primary water resources (including fresh water, soft water and salt water which are produced by fresh water) and secondary water resources (namely recycled water, including circulation water, series water and reused water).

\section{WATER COST MODEL IN IRON AND STEEL ENTERPRISE}

The water cost per ton steel in iron and steel enterprise mainly contains fresh water cost, recycled water cost, environmental protection cost. The mathematical model of water cost perton steel in iron and steelenterprise is

$$
C=\sum_{i=1}^{n} \mathrm{C}_{i}
$$

Where, $C$ is the water cost per ton steel, RMB/t-steel; $C_{i}$ is all kinds of water fee, including fresh water cost, recycled water cost, environmental protection cost, and other miscellaneous cost, RMB/t-steel.

\section{A. Fresh water cost}

Fresh water cost is related to regional water resources fee of the steel industry, water price, quantity of intaking water, and weather purification. The equation of fresh water cost is

$$
C_{1}=W_{f} \square p_{f}
$$

Where, $C_{1}$ is fresh water cost per ton steel, $\mathrm{RMB} / \mathrm{t}$ steel; $p_{f}$ is the price of fresh water, $\mathrm{RMB} / \mathrm{m}^{3}$.

\section{B. Recycled water cost}

Recycled water cost contains electric charge, water treatment medicament cost, labor cost, maintenance cost, depreciation cost and so on. It is related to the level of clean production and water-saving and emission reduction in iron and steel enterprise, including recycled water quantity, water quality, water circulation rate, concentration ratio of circulating water system, medicament cost, level of water treatment facilities, etc. The equation of recycled water cost is

$$
C_{2}=\sum_{\mathrm{i}=1}^{3} W_{i} \square p_{i}
$$

Where, $C_{2}$ is recycled water cost per ton steel, RMB/tsteel; $W_{i}$ is recycled water quantity which is the sum of the quantity of circulation water, series water and reused water; $p_{i}$ is the price of fresh water, $\mathrm{RMB} / \mathrm{m}^{3}$. 


\section{Environmental protection cost}

The environmental protection cost in iron and steel enterprise is mainly composed of wastewater treatment cost, drainage and sewage charge, environmental fines, etc.

Wastewater discharge includes two parts, one is comprehensive wastewater, and the other part is wastewater from process production. So wastewater treatment cost includes comprehensive wastewater treatment cost and process wastewater treatment cost.

Drainage and sewage charge is calculated by the standard of the region.

Environmental fines are the fines beyond the national and local emission standards, according to the standard of the local environmental protection department.

\section{ANALYSIS OF WATER COST PER TON STEEL IN IRON AND STEEL ENTERPRISE}

\section{A. Analysis on the change of water cost per ton steel in iron and steel enterprise}

At the beginning of the 10th Five-year, the water circulation rate in iron and steel enterprises was low (average was $80 \%$ ), water was directly used but no comprehensive sewage treatment and reuse. Water treatment was simple and mainly aimed at muddy water, and treated water was mostly let out without reuse. Water cost was main ly embodied in intaking water cost. Intaking water consumption per ton steel in iron and steel enterprise was $6 \sim 150 \mathrm{~m}^{3}$, wastewater emission per ton steel was $17 \mathrm{~m}^{3}$, circulation water consumption per ton steel was $40 \sim 157 \mathrm{~m}^{3}$, intaking water cost per ton steel was 3 15 RMB, and the water cost per ton steel was 9 50 RMB [12].

Water consumption and wastewater emission of per ton steel were reduced greatly with many water-saving projects during the 10th, 11th and 12th Five-Year Plan. Intaking water consumption per ton steel in key statistic steel enterprise in 2013 has decreased to $3.5 \mathrm{~m}^{3}$, wastewater emission per ton steel has dropped to $0.78 \mathrm{~m}^{3}$, water circulation rate has reached up to $97.61 \%$, and the water consumption indexes have reached the advanced international level. However, intaking water cost was increased with the improving water resources fee by the government because of the shortage of water resources and water pollution. The fresh water purification cost, treatment cost of circulation water and comprehensive wastewater treatment cost. At present, intaking water consumption per ton steel in key steel enterprise is 3.5 6 $\mathrm{m}^{3}$, wastewater emission per ton steel is $0.78 \mathrm{~m}^{3}$, circulation water consumption per ton steel is $150 \sim 200 \mathrm{~m}^{3}$, circulation water cost per ton steel is $2 \sim 36 \mathrm{RMB}$, intaking water cost per ton steel is 2 36 RMB, water cost per ton steel is 40 156 RMB [13].

Water cost per ton steel in iron and steel enterprise has increased 2 4 times than the 10th Five-year, and it is different between different industries because of the different processes constitution, product structure, level of using water, the local resource condition.

A typical iron and steel enterprise in northeastern of China is analyzed as followed.

\section{B. Analysis of water cost per ton steel in a typical iron and steel enterprise}

According to the survey, the fresh water consumption per ton steel in the typical iron and steel enterprise is 4.03 $\mathrm{m}^{3}$ in 2014 , and the wastewater emission per ton steel is $2.02 \mathrm{~m}^{3}$; water sources contain groundwater and river water, water is processed to the fresh standard after purification treatment before provided to the user; each production process and auxiliary process are installed with independent circulating water treatment facilities, perfect water quality stabilization system and facilities, a high degree automation of dosing system, circulation water system with bypass filtration unit, sludge treatment facilities, etc; the circulation rate of circulating water system reaches up to $97.5 \%$, the repeated utilization ratio of the plant is 98\%; a comprehensive wastewater treatment plant is established in the enterprise, which can treat the sewage from all the processes into clean circulation water, industrial fresh water, salt water with physical and chemical processing system, deep processing system, water desalination system; the reused water return to each process and form a large water cycle of the enterprise.

As shown in TABLE I, the water cost per ton steel in the enterprise is $176.72 \mathrm{RMB}$, which is much higher than advanced iron and steel enterprise that is 126.9 $\mathrm{RMB} \sim 151.9 \mathrm{RMB}$. And fresh water cost $C_{1}$ is $11.77 \mathrm{RMB}$ which accounting for $6.66 \%$ of the total water cost, recycled water cost $C_{2}$ is $137.56 \mathrm{RMB}$ which accounting for $77.84 \%$, environmental protection cost $C_{3}$ is 27.4 RMB which accounting for $15.5 \%$.

The four reasons for the high water cost per ton steel as follows:

1) Large quantity of fresh water consumption: the fresh water consumption per ton steel is $4.03 \mathrm{~m}^{3}$, which is higher than the average of the key iron and steel enterprise in China.

2) Large amount of wastewater emission: the concentration ratio of the subsystem is low, which causes large amount of wastewater emis sion.

3) Large water treatment quantity of circulation water: Large wastewater emission causes large amount of circulation water and treatment water, and causes the increase of electric charge, water treatment medicament cost, labor cost, maintenance cost, depreciation cost, area, and causes the overall operating cost raising.

4) High centralized wastewater treatment cost: most of the wastewater is centralized treated by the comprehensive wastewater treatment plant, and then go back to the enterprise, which increases the processing cost of the reused water.

In conclusion, for reducing the water cost of the enterprise, the first is to reduce the intaking water consumption and process water consumption [14]; the second is to reduce drainage, emissions, improve the concentration ratio and the circulation rate; the third is to treat wastewater in a classified and local manner.

\section{THE METHODS OF WATER CONSERVATION, EMISSION REDUCTION AND COST REDUCTION PER TON STEEL}

Based on the water cost model and analys is of water cost per ton steel in iron and steel enterprise, the methods 
of water conservation, emission reduction and cost reduction are shown as follows:

- process water cost per ton production is analyzed [15], the key water users are found out, strategies for water saving and emissions reduction are given, laggard technologies, equipments are remolded or weeded out, and the circulation utilization ratio of water system is improved, fresh water consumption and wastewater discharge from the source are reduced, the water cost is reduced.

- The higher the circulation utilization ratio is, the lower the water consumption is; the smaller the fresh water cost $C_{1}$ is, the higher the recycled water $\operatorname{cost} C_{2}$ is. Therefore, the water circulation rate is increasing and fresh water consumption is decrease with the rising cost of water at the same time, and the optimal circulation rate must be found out in the minimum $\cos t C$.

- The quantity of wastewater treatment should not be particularly big because the cost of wastewater treatment is much higher than fresh water cost. At the same time, the research and management of water treatment equipment and technology should be strengthened for the wastewater treatment cost reached up to be minimal.

- Wastewater should be dealt with by classification and should not be dealt after all together which can increase the processing difficulty, so the big circulation should be avoided for a small circulation using local treatment model.

- Fresh water consumption quota is formulated which can manage each users, and the measurement of operation and measure should be strengthened instead of indiscriminate use and disorderly sewage.

\section{CONCLUSIONS}

Water cost per ton steel occupies an important share in controllable cost in iron and steel enterprise. The paper establishes water cost model in iron and steel enterprise, analyzes the change of water cost per ton steel a decade and the water cost in a typical iron and steel enterprise in China. The results of which are:

- Water cost per ton steel in iron and steel enterprise has increased 2 4 times than the 10th Five-year.

- The water cost per ton steel in iron and steel enterprise mainly contains fresh water cost, recycled water cost, environmental protection cost.

- The methods of water conservation, emission reduction and cost reduction are: reducing fresh water cost $C_{1}$ with reducing fresh water consumption; reducing recycled water $\cos t C_{2}$ and environmental protection cost $C_{3}$ with reducing wastewater emission; reducing fresh water consumption and wastewater discharge from the source; reducing the water cost.

\section{ACKNOWLEDGMENT}

This study was supported by the Water Pollution Control and Treatment (2012ZX07202-001-003), and supported by the Open Research Fund of Key Laboratory for Ferrous Metallurgy and Resources Utilization of Ministry of Education of Wuhan University of Science and Technology. The authors thank all the members in the projects.

\section{REFERENCES}

[1] Z. Zhaobin, "Reduce water consume of per ton steel to realize saving energy and reducing pollutant emission," Metallurgical Power, no. 6, 2009,pp.33-35.

[2] G. Chengkang, D. Wang, and D. Hui, "Optimization and evaluation of steel industry's water-use system," Journal of Cleaner Production, vol. 19, 201 1, pp. 64-69, doi:10.1016/j.jclepro.2010.08. 013.

[3] T. Yongjuan, C. Jiuju and L. Ziqiang, "Analysis of water-saving, emission reduction and reducing water cost per ton steel," Energy for Metallurgical Industry, vol. 33, Sep. 2014, pp. 54-56.

[4] W. Shaowen, Q. Lei and Z. Yuanlong, Technology and application of wastewater resources reusing in iron and steel industry. Beijing: Metallurgical Industry Press, 2008.

[5] Y. Zhiqiang, Analysis and Water-Saving Research on Water Circulation System of Ansteel. Shenyang: Northeastern University, 2009.

[6] Y. Ruiyu, "Development and evaluation on chinese steel industry," Acta Metallurgical Sinica, vol.38, Jun. 2002, pp.561-567.

[7] C. Xiangli, Analysis of water in rion and steel industry. Beijing: Iron and Steel Research Institute, 2005.

[8] D. Hui, Y. Zhiqiang, X. Shengyan and D. T ao, "Construction and application of water flow chart in coking process," Iron and Steel, vol.45, July2010, pp. 89-93.

[9] Mohan Yellishetty, "Substance flow analysis of steel and long term sustainability of iron ore resources in Australia, Brazil, China and India," Journal of Cleaner Production, vol. 84, 2014, pp. 400-410, doi. 10.1016/j.jclepro.2014.02.046

[10] L. Zhongwu, "The following-observing method for substance flow analysis," Engineering Science, vol.8, Jan. 2006, pp.18-25.

[11] L. Zhongwu, "The following-observing method for substance flow analysis," Non-ferrous Metals Recycling and Utilization, 2006, pp. 27-28.

[12] W. Jian jun, Study on material flows, energy flows and material flow-energy flow relationship in iron \& steel factory. Shenyang: Northeastern university, 2008.

[13] L. Chunfeng, "Analysis of water costs and environmental costs in iron and steel industry," Metallurgical economics and management, no. 2, 2013, pp. 26-30.

[14] L. Zhihai, "Strengthening the water management of production, reducing water cost of per ton steel," Metallurgical Financial Accounting, no. 12,2002, pp. 19-21.

[15] W. Weixing, "Research supporting condition of technology and equipment, realize scientific water saving in branch operation," China metallurgical News, July 12, 2015. 
T ABLE I. THE WATER COST PER TON STEEL IN A TYPICAL IRON AND STEEL ENTERPRISE IN 2014

\begin{tabular}{|c|c|c|c|c|c|}
\hline No. & Name & Price/RMB/ $\mathbf{m}^{3}$ & Water consumption $/ \mathrm{m}^{3} / \mathrm{t}-\mathrm{s}$ & Water cost/RMB/t-s & Percentage/\% \\
\hline 1 & Fresh water cost, $\mathrm{C}_{1}$ & 2.92 & 4.03 & 11.77 & 6.66 \\
\hline \multirow{7}{*}{2} & Recycled water cost, $\mathrm{C}_{2}$ & - & - & - & - \\
\hline & Circulation water, $W_{c}$ & 0.6 & 200 & 120 & 67.90 \\
\hline & Series water, $W_{s}$ & - & - & - & - \\
\hline & Reused water, $W_{u 1}$ & 0.889 & 15.4 & 13.69 & 7.75 \\
\hline & Reused water, $W_{u 2}$ & 0.924 & 4.07 & 3.76 & 2.13 \\
\hline & Reused water, $W_{u 3}$ & 2.622 & 0.04 & 0.10 & 0.06 \\
\hline & Total & - & - & 137.56 & 77.84 \\
\hline \multirow{7}{*}{3} & Environmental protection cost, $\mathrm{C}_{3}$ & - & - & - & - \\
\hline & Comprehensive wastewater treatment cost & 3 & 3 & 9.00 & 5.09 \\
\hline & Process wastewater treatment cost & 0.6 & 20 & 12.00 & 6.79 \\
\hline & Coking wastewater treatment cost & 12 & 0.25 & 3.00 & 1.70 \\
\hline & Drainage and sewage charge & - & 2.02 & 3.33 & 1.89 \\
\hline & Environmental fines & - & - & 0.07 & 0.04 \\
\hline & Total & - & - & 27.40 & 15.50 \\
\hline 4 & Total & - & - & 176.72 & 100.00 \\
\hline
\end{tabular}

